\title{
Developing Halal Tourism (Syari'ah): Investigating The Role Of Intellectual Capital, Organizational Citizenship Behavior, And Spiritual Capital
}

\author{
Agus Ariyanto ${ }^{1}$, Juli Dwina Puspita sari ${ }^{2}$, Marlizar $^{3}$, Nurmala $^{3}$, Husnaina Mailisa Safitri ${ }^{3}$ \\ \{mr.agusariyanto@gmail.com; jujue.js@gmail.com; marlizar.alie@gmail.com; \\ malayudi77@gmail.com; husnaina.mailisasafitri@gmail.com\} \\ ${ }^{1}$ Department of Management, University Muhammadiyah Aceh, Aceh, Indonesia \\ ${ }^{2}$ Department of Management, Faculty of Economics and Business, IAIN Cot Kala, Aceh, Indonesia \\ ${ }^{3}$ Department of Management,Economics Faculty,University of Muhammadiyah Aceh, Aceh, \\ Indonesia
}

\begin{abstract}
This research aims to test and analyze the role of intellectual capital, spiritual capital and OCB in improving organizational performance at the Tourism Office of Banda Aceh. A survey which uses multiple regressions as the data analysis method is applied. The respondents consist of 75 employees of Aceh Tourism Department and convenience sampling is utilised. This study finds that the role of $\mathrm{IC}, \mathrm{SpC}$ and $\mathrm{OCB}$ in influencing organizational performance are proved to be positive and significant. Simultaneously, the influence of IC, SpC and OCB are able to explain and influence the organizational performance variable (73.3\%). Hence, Banda Aceh Tourism Department should focus on building organizational resources, providing various skills and implementing reward systems for outstanding employees. Realizing and reinforcing Islamic organizational culture as the basis for of employee behavour and identity. Establish cooperation between agencies related to the development of sharia tourism in Banda Aceh. The achievement of performance for non-profit organizations is not assessed by how much profit the company generates but rather on how the community feels satisfied with the services and pro-people policies given by the organization.
\end{abstract}

Keywords: Islamic Tourism, Intellectual Capital, Spiritual Capital, OCB, Organizational Performance

\section{Introduction}

Today, Islamic economics is an important element in the development of global economy. In Islamic Economics, at leastthere are 7 important sectors that continue to grow, namely the culinary sector, finance and Islamic banking, insurance industry, fashion, cosmetics, pharmaceutical, entertainment, and tourism, all of which carry the concept of halal in each of its products. Discussing about the definition of the concept of halal then what will come to mind of public in general is the product of cosmetics, drugs and food drinks that contain no alcohol andother "haram" raw materials. Nowaday, an evolution in the halal industry to 
financial products (such as banking, insurance, etc.) and lifestyle products (travel, hospitals, recreation and medicine) is salient. One sector of Islamic economic growth is experiencing rapid growth is the tourism sector of sharia. Sharia tourism is different from religious tourism which is generally understood byIndonesian as visiting the graves of ulama (religious figures), mosques, and other sites of Islamic relics. Sharia tourism has a broader range of cultural, natural, culinary, cosmetic and spa (beauty) tours, shopping, travel and more.

The rapid growth of world population is the reason for the rapid growth of sharia tourist trends in various parts of the world. According to a research note by the [1], the Muslim population in 2010 was 1.599 billion or 23.2 percent of the world's population and estimated by 2050 the world's Muslim population will be accounted for 2.761 billion or 29.7 percent of the world's total population. The growth of population from 2010 to 2050 has grown to 1.161 billion people. The population of Muslim is the secondto the Christian population of 2.168 billion in 2010 or 31.4 percent of the total world population, while the increase in the number of Christian population up to 2050 is only 749 million. Table 1 belowindicates the growth of Muslim population of the world compared to other residents

Table 1. Number and Prediction of Population Growth by Majority Religion Group in the World Year 2010 - 2050

\begin{tabular}{|c|c|c|c|c|c|}
\hline & $\begin{array}{l}2010 \\
\text { POPULATIO } \\
\text { N }\end{array}$ & $\begin{array}{l}\text { \%OF } \\
\text { WORLD } \\
\text { POPULATIO } \\
\text { N IN } 2010\end{array}$ & $\begin{array}{l}\text { PROJECTED } \\
2050 \\
\text { POPULATIO } \\
\text { N }\end{array}$ & $\begin{array}{l}\text { \%OF } \\
\text { WORLD } \\
\text { POPULATIO } \\
\text { N IN } 2050\end{array}$ & $\begin{array}{l}\text { POPULATIO } \\
\text { N GROWTH } \\
2010-2050\end{array}$ \\
\hline Christians & 2.168 .330 .000 & 31,4 & 2.918 .070 .000 & 31,4 & 749.740 .000 \\
\hline Muslims & 1.599.700.000 & 23,2 & 2.761 .480 .000 & 29,7 & 1.161 .780 .000 \\
\hline $\begin{array}{l}\text { Unaffiliate } \\
\text { d }\end{array}$ & 1.131 .150 .000 & 16,4 & 1.230 .340 .000 & 13,2 & 99.190 .000 \\
\hline Hindus & 1.032 .210 .000 & 15,0 & 1.384 .360 .000 & 14,9 & 352.140 .000 \\
\hline Buddists & 487.760 .000 & 7,1 & 486.270 .000 & 5,2 & -1.490 .000 \\
\hline $\begin{array}{l}\text { Folk } \\
\text { religions }\end{array}$ & 404.690 .000 & 5,9 & 449.140 .000 & 4,8 & 44.450 .000 \\
\hline $\begin{array}{l}\text { Other } \\
\text { religions }\end{array}$ & 58.150 .000 & 0,8 & 61.450 .000 & 0,7 & 3.300 .000 \\
\hline Jaws & 13.860 .000 & 0,2 & 16.090 .000 & 0,2 & 2.230 .000 \\
\hline $\begin{array}{l}\text { World } \\
\text { total }\end{array}$ & 6.895 .850 .000 & 100,0 & 9.307 .190 .000 & 100,0 & 2.411.340.000 \\
\hline
\end{tabular}

Source: world religions' future: Projection of population growth 2010-2050 (PEW research centre, 2015)

Additionally, according to [2] publication data from 55 countries in the Global Islamic Economy Report 2016 - 2017, the total world Muslim expenditure in the halal food and beverage sector in 2015 reached US \$ 1.173 billion or equal to 16.6 percent of food expenditure and drink the world's population. This expenditure will reach US \$ 1.914 trillion or 18.3 percent of global food and beverage expenditure by 2021 . In travel sector 2015 , the Muslims worldwide spend about US \$ 151 billion for travel or about 11.2 percent of global spending. It is estimated that the number will continue to increase to US \$ 243 billion or 12.3 percent of global travel sector expenditure in 2021 (excluding Hajj and Umrah). In the fashion sector, Muslim worlds spend aboutUS \$ 243 billion or 11 percent of global spending by 2015 and this number is expected to reach US \$ 368 billion by 2021 [2]. Based on these data, the magnitude of the World Muslim market potential is certainly very tempting for the tourism business both the global business as well as Indonesia. 
The tourism industry poses a significant role in the government development program in region. Several regions in Indonesia define the tourism sector as a major focus in increasing local revenue and income sources for the people. Sharia tourism activities have become an industry with a rapid growth not only in Indonesia but also in the world. Aceh province which implements Islamic law in social governance and social sytem, views that the current sharia tourism has a great potential to be developed in Aceh. Along with the hope of a superior Islamic tourism, it will beable to provide economic benefits both to the Government of Aceh and its people.

To become one of the main Sharia Destination (DTW) in Indonesia, through the Tourism Department, Banda Aceh should be able to rearrange its program. Rearranging by providing convenience element through its policy / regulation, provision of tourism infrastructure and non-infrastructure. Non infrastructure defined as the Human Resources (employees) readiness. Sincethrough employees who have intellectual capital, motivation, skills, commitment, morale, and responsibility to the task, it will create an organizational atmosphere that supports the mission and organizational goals which is making Banda Aceh as the leading DTW sharia in Indonesia.

Ministry of Tourism and Creative Economy of Indonesia which acts as a locomotive (responsible) of the main development of Islamic tourism in Indonesia, has prepared various strategies to promote sharia tourism in Indonesia. With the preparation of strategic steps to accelerate the development of Islamic tourism such as formulating promotional strategies, regulation, building standardized infrastructure, carrying out socialization and education. However, among the various strategies formulated by the Ministry of Tourism and Creative Economy to promote sharia tourism in Indonesia, the readiness of Human Resource (HR) which acts the perpetrator of Islamic tourism, yet still defined as an aspect that is not less important to note. Without human resources as a source of intellectual capital (intellectual capital) excel in the organization, it will be difficult for sharia tourism to grow in Indonesia.

The intellectual capital factor is crucial to the progress of modern organizations today. Different from profit-based organizations that require intellectual capital to maximize performance through the achievement of corporate profit targets; a non-profit organizations such as government agencies are also required to have maximum performance. Yet the measure of organizational performance is not judged by corporate profits, but rather from productivity, effectiveness, service quality, and accountability [3].

The development of Islamic tourism in Indonesia cannot be separated from the importance of the role of human resource factor (intellectual capital) that works in tourism offices throughout Indonesia as an organizational resource. The tourism office in the region / province under the command of the Ministry of Tourism (KEMENPAR) RI, is responsible for the development and implementation of tourism in the relevant region / province. The issuance of pro-tourist regulations, tourism stakeholders and the formulation of appropriate targeted promotional strategies is a heavy responsibility to be undertaken by the tourism office. Without the support of qualified intellectual capital, it is difficult for sharia tourism in the region / province to grow.

In addition to the intellectual aspects of employees who are able to determine the success of an organization, there are other aspects that affect employees in behaving towards the organization, namely spirituality (spiritual capital) and OCB. [4] explain that the intrinsic values of spirituality can control how an employee behaves in certain situations. Even the value of spirituality that employees have will motivate employee behavior and enable to contribute more both to the organization and to society [5]. OCB's role is also crucial since employees with OCB properties will improve organizational efficiency and effectiveness[6] 
[8]. Thereforethefocus of the research is to examine and analyze the role of intellectual capital, spiritual capital and OCB in improving organizational performance at the Tourism Office of Banda Aceh.

\section{Literatur review}

\subsection{Intelectual Capital (IC)}

In the [9], it is explained that intellectual capital is essentially a collection and synergy of knowledge, experience, invention, innovation, market share and community that can impact on a company's performance. IC is the ownership of knowledge, organizational technology, applied experience, professional skills and customer relationships which act as a competitive advantage for a company. IC plays an important role as an entity that includes knowledge, experience, invention, innovation, market and community share that can impact a company's performance [10]. According to [11], IC is the brain and the future of every company. The IC consists of knowledge that increases the value of a company such as; management, technology, consumer and supplier skills, patents, and processes. IC has three main components namely structural capital, human capital, and relational capital [12], [13].

\subsection{Human Capital (HC)}

Alipour (2012, in [14] defines HC as a resource or asset that assigns value to a company. $\mathrm{HC}$ plays a key role in promoting the dynamics of value creation of products and services offered by companies as well as good customer relationships. In line with the conceptKhalique et al (2015) argues that $\mathrm{HC}$ is the most important variable of IC that includes knowledge, education, skills and loyalty to the organization and motivation of employees, and is very vital for business organizations[16]. [17] argues that HC reflects the factors of employee experience, intelligence, training, relationships among all stakeholders within the company.

\subsection{Structural Capital (SC)}

SC consists of intangible assets as well as technological infrastructure whichintermediates the flow of knowledge in order to excel the operational efficiency of the company [18]. [12] explains that SC is a concept that includes the structure and mechanism of an organization. SC consists of many components, among others; databases, organizational culture, information systems,copyrights, patents, trademarks, innovation, teamwork, orientation of quality transfer of knowledge and others. SC plays as a mechanism and structure that helps to achieve the fulfillment of employee duties to the optimum point of intellectual performance and to overall company performance.

\subsection{Relational Capital (SC)}

$\mathrm{RC}$ is defined as a value that is formed from relationship that the company built to its consumer and marketing channels (Ariawan et al, 2016). RC is a knowledge that comes from its relationships with the company's stakeholders. RC is established through maintaining and developing high-quality relationships between organizations, individuals and groups since 
they can pose a prominent effect on the viability of a company (Mondal\&Ghosh, 2012 in Obeidat et al, 2017).

\subsection{Spiritual Capital (SpC)}

The fact that spiritual capital (SpC) is acrucial factor in understanding each aspect of life in terms of individual beliefs as well as behavior whichhas a profound impact on the economic, social and political activities of society (Palmer and Wong, 2013). Some researchers explain $\mathrm{SpC}$ as a group or individual capacity generated through a process of intrinsic values affirmation such as spirituality, which can control on how a person acts in certain situations [4]. Baker \& Smith (2010) also explains that $\mathrm{SpC}$ is a valuable value as well as a vision of the future and can motivate individuals to contribute to society. The concept of $\mathrm{SpC}$ has been absorbed in many fields of science and one of them is management and leadership. It is mentionedthat $\mathrm{SpC}$ is implemented through the application of the spiritual intelligence that employees or individuals have to the organizational level (Zohar \& Marshall, 2004 in [4]). According to Farsani et al. (2013) in[19], SpC and employee character are elements that play a key role in an organization's success.

Considering from the influence of $\mathrm{SpC}$ on the performance of the company, $\mathrm{SpC}$ is considered vital for employees and organizations since it is able to influence how employees of a company carry out its duties and how the company generates the desired profit. [20] argues that $\mathrm{SpC}$ is a growing company asset within its individual employees. It will be more useful when it is not manipulated by the company. SpC should be viewed as an independent asset in order to get the desired company performance. Spirituality in work not only creates a feeling of unity among employees, but also the feeling that employees are part of the organization.

\subsection{Organizational Citizenship Behaviour (OCB)}

OCB behavior is a form of human nature as a social being and mutual help [21]. According to [22] OCB is a form of voluntary individual behavior (employees), beneficial to the organization, does not expect to be recognized by the organization, and is spontaneous [23]. So it can be understood that OCB is a behavior that has the criteria; a) is not an official employee job descriptions [24], b) not mandatory, c) will not be rewarded by corporate rewards systems, and d) essential to organizational performance success [25]. Furthermore, Applebaum et al. (2004 in [26], defines OCB as a set of behaviors that are not official duties of an employee, but by the tasks and functions of the organization carried out effectively and to improve performance.

According to [6], if a company where employees tend to have OCB behavior, then it will improve the efficiency and effectiveness of the company. It is because employees are voluntarily willing to provide above average work [22]. Some examples of OCB include; willingness to work with colleagues, doing extra tasks without complaint, helping others, using time efficiently, maintaining corporate resources, sharing ideas and representing organizations positively [27]. Based on the amount of benefits the company will gain from OCB, the company's management should be able to motivate its employees to behave in an OCB by creating a conducive and supportive work environment or even a special reward system for employees with OCB [28]. OCB can be categorized into 7 types (Podsakoffet al., 2000 in [29]: (1) help-oriented behaviors, (2) sportsmanship, (3) individual growth, (4) organizational commitment, (5) individual innovativeness, (6) civic virtue, (7) selfsatisfaction. 


\subsection{Organizational Performance}

In many studies, organizational performance has always become an subject to be researched as well as acts as a dependent variable, and has become a very common study [30], [31]. The scope of the discussion on organizational performance typically includes financial factors, physical assets, employees, and other organizational assets that companies use [17].In many modern studies, organizational performance is always defined as the company's ability to generate financial performance (profit) of a company [13], such as return on investment (ROI), return on assets (ROA),return on equity (ROE) and etc. While Ling and Hong (2010, in [13]believe that company performance is the overall achievement of all organizational units involved in achieving organizational goals (vision-mission). From this understanding, it can be seen that the organization's performance shows the extent to which the level of achievement of the taskswithin an organization, an effort to realize its aims, mission, as well as vision of the organization.

The performance of the organization in many studies was measured using financial performance indicators [32]-[34], indicators of balance score cards (Kaplan and Norton, 1982 in [35] and sucess dimension [35] and Dvir, 1996 in [35]. While in research [36], non-profit organization performance is measured using quality of working environment; donations; increased rate of beneficiaries/funders; increased rate of volunteers; increased rate of members, level of competence of collaborators, and degree of perceived social image. In [35], organizational performance was measured using 5 indicators, namely financial, customer $/$ market, process, people development, and future, which include:

- Financial defined as a financial indicator such as profits, return on investment,sales figures, return on assets, return on equity, etc.;

- Customer / market defined as a relationsip formedbetween the company and its customers. Companies that strive to meet every customer's needs and desires in product design, strive to provide customer satisfaction through excellent service and products;

- Process defined as the company's achievement of efficiency in its operational process and production (TQM), learning organization, team cohesiveness, etc.;

- People development defined as an indicator of organizational success due to employee training programs, employee development, employee commitment, and leadership roles;

- Future defined as an organization's planning on current issues such as strategic planning, an analysis for any changes in the business environment,partnership planning and partnerships, and investment in new markets / segments and investments in technology.

\subsection{IC Relationship on Organizational Performance}

Researches examining IC relationships on organizational performance have been widely used [9], [13], [16], [37]-[39]. Other studies more specifically found that the IC components consisting of HC, SC, and RC, positively impacted the company's performance [10], [40].

The results of [10] revealed that there is a significant influence between IC on company performance, in addition to positive and significant relation on company performance, even $\mathrm{HC}$ and SC also act as a moderating variable. [40] found that three IC dimensions improve organizational performance on a number of companies that become object in their research, [40] also explained that confidence is the determining factor in developing the dimensions of IC, namely HC, SC, and RC. While [41] revealed that the IC has a significant and positive effect on the performance of the company, where the relational capital component becomes the main predictor of performance. 
Hypothesis 1: IC has a positive and significant effect on organizational performance

\subsection{SpC Relationship on Organizational Performance}

Research on the relationship between $\mathrm{SpC}$ on organizational performance undertaken by [14] and [42] indicated that $\mathrm{SpC}$ variable has a positive and significant effect on organizational performance. [19] in their research on the influence of $\mathrm{SpC}$ on organizational performance found that $\mathrm{SpC}$ has a positive impact on corporate financial performance. Similar research by [20] also states that $\mathrm{SpC}$ has a positive influence on performance of a company since $\mathrm{SpC}$ is considered as a form of intelligence that can give strength to employees.

Hypothesis 2: $\mathrm{SpC}$ has a positive and significant effect on organizational performance.

\subsection{OCB Relationship on Organizational Performance}

OCB acts as a mediator on [27], but in [43]OCB's role as mediator is not proven, but OCB is vital in improving the service performance of public organizations. This study examines the relationship between trust in organizations on employee productivity, with $\mathrm{OCB}$ as a mediating veriabel. In the research of [6] and [26], the OCB is pivotal in improving organizational performance, in which the OCB business of employees is able to increase corporate profits and increase customer satisfaction and loyalty. In [44] study also revealed the result that OCB poses a significant and positive effect on organizational performance. While the [45] study showed that OCB is able to improve hospital performance, and also improve the company's image.

Hypothesis 3: OCB has a positive and significant effect on organizational performance.

Table 2. Tabel 2. Validity Test

\begin{tabular}{|c|c|c|c|c|c|c|c|c|c|c|}
\hline \multirow[t]{2}{*}{ Construct } & \multicolumn{9}{|c|}{ Pearson Correlation } & \multirow{2}{*}{$\begin{array}{l}\text { df }=73 \\
P=0,05\end{array}$} \\
\hline & 1 & 2 & 3 & 4 & 5 & 6 & 7 & 8 & 9 & \\
\hline Intellectual & ,688 & ,745 & ,780 & ,715 & , 470 & ,280 & ,686 &, 570 & - & \\
\hline Capital & & & & & & & & & & $\begin{array}{l}\mathbf{r} \text { table } \\
0.227\end{array}$ \\
\hline Spiritual Capital & ,516 & ,448 & ,581 & ,514 & ,593 & ,532 & ,370 & ,548 & & \\
\hline OCB & ,396 & ,532 & ,584 & ,610 & ,524 & ,659 & ,543 & ,528 & - & \\
\hline $\begin{array}{l}\text { Organization } \\
\text { Performance }\end{array}$ & ,593 & 648 & ,509 & ,579 & 691 & ,380 & ,511 & ,502 & ,563 & \\
\hline
\end{tabular}

\section{Methods}

This type of research is confirmatory with survey method. Using a questionnaire (Likert Scale), Data collected at Banda Aceh Tourism Office, which was addressed to employees who worked at the City of Banda Aceh Tourism Office. Convenience sampling tehnique is utilisied. The data will be tested for validity using pearson correlation where kuesioenr data is 
said valid if value of pearson correlation $>\mathrm{r}$ table $(0,227)$, while reliability testing using cronbach's alpha $(\mathrm{CR}>0,70)$. Multiple regressionsis used as the data analysis (t-test and Ftest).

Measurement of variable intellectual capital using indicators of skills, knowledge \& expertise, attitude and intellectual agility, infrastructure and systems, policies and procedures, customer satisfaction \& loyalty; the measurement of spiritual capital variable uses indicators of knowledge of religious, ethical values [15]. Measurements of OCB variables use sportmanship indicators, civic virtue, conscientiousness, and altruism [6]. While the variable organization performance using indicators customer / market, process, people development, and future [35].

\section{Result}

From the questionnaire results obtained demographic data of respondents, where it is known that male respondents amounted to 36 people $(48 \%)$, while female respondents amounted to 39 people (52\%). Employees who work at the City of Banda Aceh Tourism Office have a majority of 35-39 year olds (32\%), with a majority of over 6 years (24\%).

Table 2 shows the test results of the validity of the research questionnaire, where the item questionnaire is considered valid if it has a pearson correlation $>r$ table (0.227).

The test results of 33 questionnaires indicate that the whole item of the questionnaire has been valid.

While testing the questionnaire, the reliability can be known from Table III. Research variables are said to have good reliability if it has a value of cronbach's alpha greater than 0.70 . In the spiritual variable capital the value of cronbach's alpha is 0.600 and in the OCB variable the cronbach's alpha value is $0.658(<0.70)$, but the value of 0.6 is still acceptable (Hair et al., 2006, p 102). So in this study all research variables have good reliability.

Table 3. Scale Reliability

\begin{tabular}{ll}
\hline Construct & Cronbach's Alpha \\
\hline Intellectual Capital & 0,773 \\
Spiritual Capital & 0,600 \\
OCB & 0,658 \\
Organization Performance & 0,707 \\
\hline
\end{tabular}

Hypothesis testing in this research use multiple regression method. This method is used to test and explain the causal relationship between research variables shown in the series of path analysis model [46]. From the analysis of multiple regression, the results obtained in Table IV show that all hypotheses are supported positively and significantly ( $\operatorname{sig}<0,05)$.

Table 4. Hypothesis Testing

\begin{tabular}{lcccc}
\hline Construct & Sig & $\begin{array}{c}\text { Correla } \\
\text { tions }\end{array}$ & F test & $\begin{array}{c}\text { R } \\
\text { Square }\end{array}$ \\
\hline Intellectua & 0,000 & 0,824 & 65,091 & 0,733 \\
l Capital & & & Sig= & \\
$\begin{array}{l}\text { Spiritual } \\
\text { Capital }\end{array}$ & 0,027 & 0,688 & 0,000 & \\
\hline
\end{tabular}




\begin{tabular}{lll}
\hline $\mathrm{OCB}$ & 0,049 & 0,459 \\
\hline
\end{tabular}

Table IV shows the results of hypothesis testing, where the relationship of IC effect on organizational performance proved to have positive and significant relation, ie significant value $0,000<0.05$ ( $\mathrm{H} 1$ accepted). In relation of influence of $\mathrm{SpC}$ to organizational performance also significant, significant value $0,027<0,05$ (H2 accepted).

While the hypothesis that there is influence between OCB on organizational performance also proved significant, ie significant value $0.049<0.05$ (H3 accepted). The simultaneous effect test between independent variable to dependent variable is shown through F-test. Where it is known that simultaneously there is influence of IC, SpC and OCB to organizational performance $(\mathrm{F}$ test $=65,091<\mathrm{F}$ table $=2,73$ ). Then the square $\mathrm{R}$ square is 0.733 , which means that as much as $73.3 \%$ variations of IC, SpC and OCB are able to explain and influence organizational performance variables, while as much as $26.7 \%$ is explained by other variables outside the model.

\section{Discussion}

The development of the modernization of the world has brought about rapid changes in the economic field. The world's economic development requires businesses to adapt competitive strategies to win global competition and survive in industrial environments. [17] explains that corporate resources are a set of factors owned by a company consisting of tangible assets (such as machinery and equipment) as well as intangible assets (employees). [47] on resource-based view provides an understanding that with the uniqueness of resources it will produce superior performance in competing, and if managed well then the company will be able to achieve sustainable competitive advantage. Companies must able to control the strategic resources of both tangible and intangible organizations. The role of an intangible resource plays a more crucial role for the company since the intangible assets (organizational resources) that are valuable, loyal, and not easily replaced and replicated are the keys to the company in winning the industry competition.

Intellectual capital as an organizational resource plays a pivotal role in improving the company's performance as well as becomes the primary source of competitive advantage over competitors. According to [10] the most important resource that a company should have in order to be able to perform well is not to tangible assets such as buildings, machinery and buildings, but most importantly, intangible assets are intellectual capital. Especially for nonprofit organizations such as the Banda Aceh City Tourism Office, organizational performance is not viewed through how much profit the company generates, how the community feels satisfied with the performance of the policies and good service to the community, this intellectual capital's role becomes very crucial [3].

In this study the overall hypothesis proved positive and statistically significant, meaning that there is the influence of IC, $\mathrm{SpC}$, and $\mathrm{OCB}$ on organizational performance at the Tourism Department of Banda Aceh City. This study proves and reinforces the findings of previous researchers who expressed the magnitude of IC's role to organizational performance [10], [12], [15], [37], [40]. The result also support the findings of previous researchers who reveals the role of SpC in organizational performance [14], [19], [20], [42]. It also support previous research hasol that proves if OCB has a positive and significant effect on organizational performance [6], [26], [27], [43], [44]. 
The interesting thing was found in this research that IC proved very dominant influence organizational performance. The correlation coefficient of IC (0.824) shows that $82.4 \%$ of variabel IC is capable of influencing organizational performance. According to [47] and [10], the role of IC as an intangible asset is important as it capable to provide a competitive advantage for the organization. In this study also reveals the great role of $\mathrm{SpC}$ in influencing organizational performance. This can be proved by looking at the correlation coefficient SpC (0.688), which shows as much as $68.8 \%$ organizational performance variables explained by $\mathrm{SpC}$ variables. The role of $\mathrm{SpC}$ in the Tourism Office of Banda Aceh City revealed that employees at the Tourism Department already have the spirit of spirituality in work. Working is considered as worship and full of sincerity. Researchers argue that this culture of spirituality is in line with the spirit of Islamic Sharia applied in Aceh, where all government and private institutions should uphold and support the enforcement of sharia.

According [14] SpC owned organization to be able to play a role in keeping every element of the organization in working / acting in accordance with legal corridors and ethics. SpC-owned organizations are also able to provide honesty motivation for individual organizations in the work. Similar opinion was also expressed by [4], that spiritual capital is also proven to have a significant effect on organizational progress, in which the intrinsic values of spirituality can control how employees behave in certain situations, and even the value of spirituality they possess employees will motivate employee behavior to contribute more both to the organization and to the community. Spirituality of employees gives influence to the way employees work, both in the attitude and behaviorof [5].

Besides the crucial role of intellectual capital and spiritual capital as the driving force of the organization, the role of OCB is also crucial in achieving the maximum performance of an organization. The results of this study also proves that OCB is capable of affecting organizational performance by $45.9 \%$ (correlation coefficient 0.459 ), if a company has employees who behave OCB, then the organization will be able to improve the efficiency and operational effectiveness of the company [6]. Employees at the Banda Aceh City Tourism Office who have an OCB attitude will tend to have an attitude of willingness to work with colleagues as a team, willing to do extra duties without complaining, helping others, using time efficiently, maintaining company resources, building organizations [27]. Finally, the attitude of OCB owned by the employees of the City of Banda Aceh Tourism Office will create an organizational atmosphere that supports the achievement of the vision and mission of organizational goals, which makes Banda Aceh as one of the leading Sharia Destination Destination in Indonesia.

\section{6 conclutions}

The organization's performance at the Banda Aceh Tourism Office is influenced by the role of IC, SpC and OCB. However, IC has the most dominant role of all independent variables in influencing organizational performance. With the existence of superior intellectual capital dilimiki by Tourism Department of Banda Aceh, is expected to be able to boost sharia tourism, and make Aceh as one of the leading tourist destination (DTW) in Indonesia.

Limitations of this study are Firstly, the limited number of samples studied, with very homogenous sample characteristics. So the result of the study only has a very narrow coverage of the Tourism Department of Banda Aceh City. Second, the absence of testing the role of 
mediation of OCB variables, which in many OCB studies often acts as a mediating variable of the influence of IC on organizational performance [27], [43].

The results of this study indicate the role of intellectual capital and spiritual capital in realizing the achievement of optimal organizational performance. Therefore, the policy implications recommended to the Tourism Office of Banda Aceh are (1) focus on building organizational resources, by providing various skills training, and applying reward system to achievers. (2) Realizing and reinforcing Islamic organizational culture (Sharia) as the basis for behave and identity for employees. (3) Establish cooperation (MOU) between institutions / Dinas / CSOs related to the development of sharia tourism Banda Aceh, as well as the form of participation of the community (stakeholder) in developing sharia tourism in Banda Aceh. This is important to make the community (stakeholder) have a sense of ownership and willing to keep the continuity of sharia tourism to continue as a source of revenue areas and people of Banda Aceh City.

\section{References}

[1] C. Hackett, A. Cooperman, and K. Ritchey, "The Future of World Religions: Population Growth Projections, 2010-2050"," 2015.

[2] T. Reuters, "State of the GLOBAL ISLAMIC ECONOMY," Dubai Cap. Islam. Econ., pp. 1-287, 2015.

[3] M. Bolton, "Public Sector Performance Measurement: Delivering Greater Accountability," Work Study, vol. 52, no. 1, pp. 20-24, 2003.

[4] D. A. Palmer and M. Wong, "Clarifying the Concept of Spiritual Capital," in Conference on the Social Scientific Study of Religion, 2013, no. 10-13 July, pp. 1-18.

[5] C. Baker and G. Smith, "Spiritual, Religious and Social Capital - Exploring Their Dimensions and Their Relationship with Faith-Based Motivation and Participation in UK Civil Society," in Sociology of Religion Group Conference, 2010, pp. 1-40.

[6] C. Barroso Castro, E. Martín Armario, and D. Martín Ruiz, "The Influence of Employee Organizational Citizenship Behavior on Customer Loyalty," Int. J. Serv. Ind. Manag., vol. 15, no. 1, pp. 27-53, 2004.

[7] J. H. Daum, "Intangible Assets-Based Enterprise Management - A Practical Approach," in PMA IC Symposium, 2005, pp. 1-19.

[8] L. J. Chelagat and A. Kemboi, "Effect of Organizational Citizenship Behavior on Employee Performance in Banking Sector, Nairobi County, Kenya," Int. J. Business, Humanit. Technol., vol. 5, no. 4, pp. 55-61, 2015.

[9] A. Ş. Örnek and S. Ayas, "The Relationship between Intellectual Capital, Innovative Work Behavior and Business Performance Reflection," in Procedia - Social and Behavioral Sciences, 2015, vol. 195, pp. 1387-1395.

[10] M. Clarke, D. Seng, and R. H. Whiting, "Intellectual capital and firm performance in Australia," $J$. Intellect. Cap., vol. 12, no. 4, pp. 505-530, 2011.

[11] S. Sumedrea, "Intellectual Capital and Firm Performance: A Dynamic Relationship in Crisis Time," in Procedia Economics and Finance, 2013, vol. 6, no. 13, pp. 137-144.

[12] N. Bontis, "Intellectual Capital: An Exploratory Study that Develops Measures and Models," Manag. Decis., vol. 36, no. 2, pp. 63-76, 1998.

[13] C.-M. Chang, "The Influence of Capital Structure on Organizational Performance at Taiwan-Listed Info-Electronics Companies: Using Corporate Governance as the Moderator," J. Int. Manag. Stud., vol. 7, no. 1, pp. 80-92, 2012.

[14] Ariawan, M. Sudarma, Djumahir, and Ghozali, "2016 the Role of Spiritual Capital , Human Capital , Structural Capital , and Relational Capital of Smes To Improving on Performance : Study," South East Asia J. Contemp. Business, Econ. Law., vol. 11, no. 2, pp. 87-94, 2016. 
[15] M. Khalique, N. Bontis, and J. A. N. bin S. A. H. Md. Isa, "Intellectual Capital in Small and Medium Enterprises in Pakistan," J. Intellect. Cap., vol. 16, no. 1, pp. 1-24, 2015.

[16] W. Wang and C. Chang, "Intellectual Capital and Performance in Causal Models Evidence from the Information Technology Industry in Taiwan," J. Intellect. Cap., vol. 6, no. 2, pp. 222-236, 2005.

[17] J. B. Barney, "Looking Inside for Competitive Advantage," Acad. Manag. Exec., vol. 9, no. 4, pp. 49-61, 1995.

[18] Y.-H. Hsu and W. Fang, "Intellectual Capital and New Product Development Performance: The Mediating Role of Organizational Learning Capability," Technol. Forecast. Soc. Change, vol. 76, no. 5, pp. 664-677, 2009.

[19] M. S. Malik and S. Tariq, "Impact of Spiritual Intelligence on Organizational Performance," Int. Rev. Manag. Mark., vol. 6, no. 2, pp. 289-297, 2016.

[20] C. Gràcia, "Spiritual Capital the New Border to Cross," J. Appl. Ethics, no. 3, pp. 115-134, 2012.

[21] D. Sawitri, E. Suswati, and K. Huda, "the Impact of Job Satisfaction, Organization Commitment, Organization Citizenship Behavior (Ocb) on Employees’ Performance," Int. J. Organ. Innov., vol. 9, no. October 2016, pp. 24-45, 2016.

[22] K. Kumar, A. Bakhshi, and E. Rani, "Linking the Big Five personality domains to organizational citizenship behavior," Int. J. Psychol. Stud., vol. 1, no. 2, pp. 73-82, 2009.

[23] J. Wen, Y. Li, and P. Hou, "Customer mistreatment behavior and hotel employee organizational citizenship behavior," Nankai Bus. Rev. Int., vol. 7, no. 3, pp. 322-344, 2016.

[24] J. Kaur and P. Kaur, "Driving in-role Performance through citizenshiP Behaviours," J. Organ. Hum. Behav., vol. 3, no. 2, pp. 42-47, 2014.

[25] S. K. Johnson, C. L. Holladay, and M. a Quinones, "Organizational Citizenship Behavior in Performance Evaluations : Distributive Justice or Distributive Justice or Injustice ?," J. Bus. Psychol., vol. 24, no. 4, pp. 409-418, 2009.

[26] G. M. Tehran, M. S. Abtahi, and S. Esmaeili, "The Relationship between Organizational Citizenship Behavior and Performance of the Staff of Qazvin University of Medical Sciences and Health Services," Int. J. Acad. Res. Bus. Soc. Sci., vol. 3, no. 9, pp. 534-542, 2013.

[27] M. H. Peikani and M. M. Shamshiri, "The Relationship Between Organizational Trust and Employee Productivity Mediating Role Organization Citizenship Behavior in Social Security Organization of Isfahan,” Int. Bus. Manag., vol. 10, no. 17, pp. 4006-4010, 2016.

[28] C. Jiao, D. A. Richards, and K. Zhang, "Leadership and Organizational Citizenship Behavior: OCB-Specific Meanings as Mediators,” J. Bus. Psychol., vol. 26, no. 1, pp. 11-25, 2011.

[29] G. Sadeghi, M. Ahmadi, and M. T. Yazdi, "The Relationship Between Organizational Citizenship Behavior and Organizational Performance (Case Study: Agricultural Jihad Organization of Mazandaran Province)," Probl. Perspect. Manag., vol. 14, no. 3, pp. 317-324, 2016.

[30] S. Alaarj, Z. Abidin-Mohamed, and U. S. B. A. Bustamam, "Mediating Role of Trust on the Effects of Knowledge Management Capabilities on Organizational Performance," in Procedia - Social and Behavioral Sciences, 2016, vol. 235, no. October, pp. 729-738.

[31] C. Gavrea, L. Ilies, and R. Stegerean, "Determinants of Organizational Performance: The Case of Romania," Manag. Mark. Challengers Knowl. Soc., vol. 6, no. 2, pp. 285-300, 2011.

[32] M. A. A. M. Harif, C. H. Hoe, and M. I. Ahmad, "The Financial and Non-Financial Performance Indicators of Paddy Farmers' Organizations in Kedah,” World Rev. Bus. Res., vol. 3, no. 1, pp. 80-102, 2013.

[33] R. B. Carton, "Measuring Organizational Performance: An Exploratory Study," 2004.

[34] P. Chearskul, "An Empirical Investigation of Performance Measurement System Use and Organizational Performance," 2010.

[35] A. C. Maltz, A. J. Shenhar, and R. R. Reilly, "Beyond the Balanced Scorecard: Refining the Search for Organizational Success Measures," Long Range Plann., vol. 36, no. 2, pp. 187-204, 2003.

[36] I. M. Macedo, J. C. Pinho, and A. M. Silva, "Revisiting the Link Between Mission Statements and Organizational Performance in the Non-Profit Sector: The Mediating Effect of Organizational Commitment," Eur. Manag. J., vol. 34, no. 1, pp. 36-46, 2016.

[37] B. Yousef Obeidat, A. Bahjat Abdallah, N. Osama Aqqad, A. H. O. M. Akhoershiedah, and M. Maqableh, "The Effect of Intellectual Capital on Organizational Performance: The Mediating Role of 
Knowledge Sharing," Commun. Netw., vol. 09, no. 01, pp. 1-27, 2017.

[38] T. Reuters, "State of the Global Islamic Economy Report," 2015.

[39] L. M. Gogan, A. Artene, I. Sarca, and A. Draghici, "The Impact of Intellectual Capital on Organizational Performance," in Procedia - Social and Behavioral Sciences, 2016, vol. 221, no. 0, pp. 194-202.

[40] K. Asiaei and R. Jusoh, "A multidimensional view of intellectual capital: the impact on organizational performance,” Manag. Decis., vol. 53, no. 3, pp. 668-697, 2015.

[41] D. F. Abdullah and S. Sofian, "The Relationship between Intellectual Capital and Corporate Performance," in Procedia - Social and Behavioral Sciences, 2012, vol. 40, no. 6, pp. 537-541.

[42] Dewi Fariha Earnest, Nur Farhana Chamian, and Maisarah Mohamed Saat, "Assessing the relationship between human capital and spiritual capital on audit firm's performance," J. Kemanus., vol. 24, no. 2, pp. 18-28, 2015.

[43] S. A. Andrew and F. Leon-Cazares, "Mediating Effects of Organizational Citizenship Behavior on Organizational Performance : Empirical Analysis of Public Employees in," EconoQuantum, vol. 12, no. 2, pp. 71-93, 2015.

[44] A. Shahin, J. Shabani Naftchali, and J. Khazaei Pool, "Developing a Model for the Influence of Perceived Organizational Climate on Organizational Citizenship Behaviour and Organizational Performance Based on Balanced Score Card," Int. J. Product. Perform. Manag., vol. 63, no. 3, pp. 290307, 2014.

[45] J. K. Obamiro, O. O. Ogunnaike, and O. A. Osibanjo, "Organizational Citizenship Behaviour, Hospital Corporate Image and Performance," J. Compet., vol. 6, no. 1, pp. 36-49, 2014.

[46] D. R. Cooper and P. S. Schindler, Business Research Methods, Twelftedit. McGraw-Hill Irwin, 2014.

[47] J. Barnay, "Firm Resources and Sustained Competitive Advantage," J. Manage., vol. 17, no. 1, pp. 99-120, 1991. 